\title{
A large hyaenodont from the Lutetian of Switzerland expands the body mass range of the European mammalian predators during the Eocene
}

Floréal Solé and Bastien Mennecart

Acta Palaeontologica Polonica 64 (2), 2019: 275-290 doi:https://doi.org/10.4202/app.00581.2018

We here present a new hyaenodont genus and species from the Lutetian locality of Egerkingen $\gamma$ (Switzerland; MP13?): Cartierodon egerkingensis gen. et sp. nov. The new taxon is represented by numerous dental elements, mostly isolated teeth. The molars show typical features of a hypercarnivorous predator such as the strong reduction of the crushing (talonid/protocone) and puncturing (metaconid) structures. The calculation of several dental indices indicates that this hyaenodont may have been a bone-cracking predator. The new taxon differs from all the hyaenodonts previously known in Europe during the Ypresian and Lutetian by its larger size, with an estimated mass of almost $29 \mathrm{~kg}$ (the size of the extant African wild dog, Lycaon pictus). Other hyaenodonts known for this period do not exceed $20 \mathrm{~kg}$. Previous authors proposed the hypothesis of an ecological limitation of the body mass, but the description of Cartierodon egerkingensis indicates instead that the European hyaenodonts continuously increased in size throughout the Eocene. We also performed a phylogenetic analysis in order to test the relationships of this new taxon: the new hyaenodont appears to be closely related to the Lutetian hyaenodont Prodissopsalis eocaenicus.

Key words: Mammalia, Hyaenodonta, Cartierodon, ecology, phylogeny, Eocene, Switzerland.

Floréal Solé [floreal.sole@ naturalsciences.be], D.O. Earth and History of Life, Royal Belgian Institute of Natural Sciences, Rue Vautier 29, B-1000 Brussels, Belgium. Bastien Mennecart [mennecartbastien@gmail.com](corresponding author), Natural History Museum Basel, Augustinergasse 2, 4001 Basel, Switzerland; Natural History Museum Vienna, Burgring 7, 1010 Vienna, Austria.

This is an open-access article distributed under the terms of the Creative Commons Attribution License (for details please see creativecommons.org), which permits unrestricted use, 
distribution, and reproduction in any medium, provided the original author and source are credited.

PaF Full text $(556.5 \mathrm{kB})$ ।

Dor 